"Analecta Cracoviensia” 51 (2019), s. 65-84 DOI: http://dx.doi.org/10.15633/acr.3633

ks. Krzysztof Gryz

ORCID: 0000-0001-7311-9780

Uniwersytet Papieski Jana Pawła II w Krakowie

\title{
Od zniszczonych butów do antropologii daru. Duszpasterska geneza personalizmu św. Jana Pawła II
}

Dorobek świętego papieża jest niezmiernie bogaty, obejmuje wiele tematów, począwszy od zagadnień filozoficznych i teologicznych poprzez społeczne, polityczne, gospodarcze czy nawet literackie. Powstawał na przestrzeni 27 lat pontyfikatu, bardzo dynamicznych dla życia Kościoła i świata, w których to wydarzeniach Jan Paweł ir brał czynny udział bądź je twórczo inspirował. Wszystko to sprawia, że jego myśl odcisnęła swoje piętno praktycznie w każdej dziedzinie ludzkiego życia i dotknęła niemal każdego tematu, i to w sposób niezwykle głęboki i przenikliwy, co sprawia, że wciąż pozostaje dla wielu inspirująca.

Swoistym wyrazem tej powszechności magisterium i posługiwania papieskiego jest fakt, że bywa określany jako „Papież Rodziny”, „Papież Młodzieży”, „Papież Ewangelizacji”, „Papież Miłosierdzia” itd., ale przede wszystkim może być nazwany „Papieżem godności człowieka”. Jeśli można wskazać na jedną zasadniczą nić przewodnią myśli i nauczania papieża - to jest nią właśnie człowiek. Człowiek, ale w podwójnej odsłonie: najpierw ten człowiek, którym jest każdy z nas, a razem $\mathrm{z}$ tym i nierozdzielnie $\mathrm{z}$ tym, ten Człowiek, który w sobie objawia Boga, który jest samym Bogiem - Jezus Chrystus. Bez Niego nie można w pełni zrozumieć siebie jako człowieka ${ }^{1}$.

1 „Człowiek, który chce zrozumieć siebie do końca - nie wedle jakichś tylko doraźnych, częściowych, czasem powierzchownych, a nawet pozornych kryteriów i miar swojej własnej istoty - musi ze swoim niepokojem, niepewnością, a także słabością i grzesznością, ze swoim 
Wyrazem tego priorytetu personalistycznego w podwójnym wymiarze chrystologiczno-antropologicznym jest pierwsza, programowa encyklika Redemptor hominis, a w niej dwa komplementarne stwierdzenia: „Jezus Chrystus jest zasadniczą drogą Kościoła” oraz w następnym punkcie: „człowiek jest pierwszą drogą, po której winien kroczyć Kościół w wypełnianiu swojego posłannictwa, jest pierwsza i podstawowa droga Kościoła”3.

\section{Początki zainteresowania tematem człowieka}

Encyklika o Chrystusie odkupicielu człowieka i o człowieku potrzebującym odkupienia była owocem wcześniejszych przemyśleń i osobistych doświadczeń papieża, jak sam mówił, przywiózł ją poniekąd z Krakowa ${ }^{4}$. Już po ukazaniu się tekstu encykliki podczas audiencji dla włoskich nauczycieli wspominał o swoim wieloletnim zainteresowaniu tematem człowieka:

Pragnę zwierzyć się wam w tym względzie, że zastanawianie się nad człowiekiem, a wcześniej jeszcze, szczególne i bezpośrednie zainteresowanie konkretnym człowiekiem, każdym poszczególnym człowiekiem - jako stworzeniem obdarzonym godnością naturalną i nadprzyrodzoną, dzięki zbieżnemu i opatrznościowemu działaniu Boga Stwórcy i Syna Odkupiciela - jest dla mnie „stanem” myślowym, który miałem od zawsze 5 .

Z punktu widzenia wyrażenia określonego przez papieża jako „stan myślowy od zawsze" interesujące jest ustalenie genezy i intelektualnej historii zainteresowania tematem człowieka w życiu Jana Pawła II. Zasadniczy problem badawczy, jaki podejmuje niniejsze opracowanie, zawiera się w pytaniu: czy można ustalić jakiś pierwotny moment, w którym rodzi się w myśli papieża szczególne zainteresowanie człowiekiem i jaka jest istotna treść tego

życiem i śmiercią, przybliżyć się do Chrystusa. Musi niejako w Niego wejść z sobą samym, musi sobie "przyswoić», zasymilować całą rzeczywistość Wcielenia i Odkupienia, aby siebie odnaleźć" (Jan Paweł II, Encyklika Redemptor hominis [dalej: RH], Lublin 1982, nr 10).

RH 13.

3 RH 14.

4 Zob. G. Weigel, Świadek nadziei. Biografia Papieża Jana Pawła II, Kraków 200o, s. 368.

5 Jan Paweł II, „Szkoła dla człowieka” sprzyja spotkaniu z Chrystusem. Audiencja dla nauczycieli szkół średnich, członków Włoskiego Katolickiego Związku Nauczycieli Szkół Średnich (3 listopada 1979), nr 3, w: Nauczanie papieskie t. II, cz. 2, s. 493. To samo powtórzył w książce Przekroczyć próg nadziei: „Zainteresowanie człowiekiem jako osobą było we mnie bardzo dawne” (s. 149). 
doświadczenia? W poszukiwaniu odpowiedzi na to pytanie naturalną rzeczą wydaje się odwołać do krakowskich początków papieskiego życia, tym bardziej, że sam papież wskazywał na to w książce Przekroczyć próg nadziei:

Człowiek interesował mnie zawsze: naprzód - na studiach polonistyki - jako twórca języka, jako temat literacki, a z kolei, gdy odkryłem drogę powołania kapłańskiego, zaczął mnie interesować jako centralny temat duszpasterski ${ }^{6}$.

Wyznanie to wskazuje, że dwa doświadczenia stanowiły dla papieża swoistą preambułę do zainteresowania osobą. Pierwsze to spotkanie $z$ literaturą i fenomen ludzkiej mowy. Język jest bowiem ucieleśnieniem myśli, jest epifanią osoby, nie tylko co do treści, ale także co do formy przekazu. Zwłaszcza jeśli treść jest dla czytelnika czy aktora w pewnym sensie „zastana”, stanowi wynik twórczości poety, jest ona poniekąd darem, który każdy aktor na swój własny sposób najpierw odbiera, a później wyraża na zewnątrz w swojej osobistej interpretacji. To doświadczenie języka poszerzyło się i nabrało szczególnego kształtu dzięki teatrowi, w którego działalność zaangażował się młody Wojtyła już w szkole średniej. Na studiach był to Teatr Rapsodyczny prowadzony przez Mieczysława Kotlarczyka. Był to szczególny teatr, którego cechą charakterystyczną było to, że koncentrował się przede wszystkim na słowie. Wszystko inne, scenografia, stroje, gestykulacja stanowiło drugorzędne znaczenie. To oddziaływanie Teatru Rapsodycznego na młodego Wojtyłę tak charakteryzuje George Weigel: „Porywała go potęga słów nie tylko w komunikowaniu idei, ale i w wydobywaniu emocji, które są równocześnie całkowicie subiektywne i całkowicie obiektywne, prawdziwe. Mowę w takim rozumieniu ożywiała bliskość pomiędzy tym, kto mówi, i tym, kto słucha"”.

Istniała też żywa świadomość, że każdy aktor na swój własny, niepowtarzalny sposób wypowiada słowo autora dramatu, bo stoi za tym osobiste przeżycie. „Słowo - wspomina te czasy Jan Paweł II - zanim zostanie wypowiedziane na scenie, żyje naprzód w dziejach człowieka, jest jakimś podstawowym wymiarem jego życia duchowego" ${ }^{8}$. Doświadczenie tak przeżywanego słowa rodzi odniesienie do jednej z interpretacji genealogii łacińskiego pojęcia persona, które bp Remigiusz z Auxerre (ok. 841-908) wywodzi od wyrażenia

6 Jan Paweł II, Przekroczyć próg nadziei, Lublin 1994, s. 149.

7 G. Weigel, Świadek nadziei..., dz. cyt., s. 55.

8 Jan Paweł II, Dar i tajemnica. W pięćdziesiąta rocznicę moich święceń kapłańskich, Kraków 1996, s. 10 . 
per-se-sonare, czyli „brzmieć samo przez siebie”: „persona dicta est eo quod per se sonat". Osoba zatem to ktoś, kto posiada własne „brzmienie”, nie jest echem, odbiciem innego dźwieku, ale posiada własną tożsamość, osoba mówi własnym głosem. Znamienny w tym kontekście jest fakt, że genealogia pojęcia osoby sięga teatru greckiego - w nim prosopon oznaczało maskę teatralną, poprzez którą aktor wyrażał wewnętrzne przeżycia bohatera. Można także przypuszczać, że poprzez teatr Wojtyła nabył intuicyjnego otwarcia na definicję osoby sformułowaną przez Boecjusza: „persona est naturae rationalis individua substantia”, która podkreśla indywidualność i niepowtarzalność osobowego istnienia człowieka.

Drugim doświadczeniem było przeżycie wojny. To tragiczne doświadczenie, które było „wstrząsającym świadectwem pogardy dla człowieka” ${ }^{10}$, miało wpływ na jego decyzję wstąpienia do seminarium. Papież stopniowo odkrywał, że istnieje wieloraka potrzeba walki o dobro i o człowieka. Ale bronić człowieka można nie tylko walcząc z tym, który zagraża jego życiu, bronić człowieka oznacza także, a może przede wszystkim, pokazując mu i umacniając jego niezwykłą godność, która najpełniej ujawnia się w jego odniesieniu do Boga. Tak rodziła się myśl o powołaniu kapłańskim. Sam o tym wspomina: „Wobec szerzącego się zła i okropności wojny sens kapłaństwa i jego misja w świecie stawały się dla mnie nadzwyczaj przejrzyste i czytelne"11. Rodził się Wojtyła - kapłan, i to kapłan o szczególnym ukierunkowaniu i wrażliwości na godność człowieka.

\section{Doświadczenie duszpasterstwa młodzieży}

W pierwszej publikacji, którą zalicza się czasem do tzw. dzieł osobistych papieża, będącej wywiadem z André Frossardem, wspominając swoją drogę intelektualnego i osobowego rozwoju, wyznaje:

Stopniowe ześrodkowanie uwagi na człowieku, na niezwykłości osoby, zrodziło się bardziej z doświadczenia i dzielenia doświadczeń z innymi niż z samej lektury ${ }^{12}$.

9 W komentarzu do dzieła mnicha z Ix wieku Seduliusza Szkota (Sedulius Scotus), In Donati artem minorem, Remigiusz z Auxerre pisze: „In artem Donati minorem commentum” (Remigius Autissiodorensis, In artem Donati minorem commentum, Leipzig 1902, s. 65).

10 Jan Paweł II, Tu mias mis au tréfonds. List apostolski z okazji pięćdziesiątej rocznicy wybuchu II wojny światowej (27 sierpnia 1989), nr 4, https://ekai.pl/papiez-na-lecie-wybuchu-wojny/.

${ }^{11}$ Jan Paweł II, Dar i tajemnica..., dz. cyt., s. 34.

${ }^{12}$ A. Frossard, „Nie lękajcie się”. Rozmowy z Janem Pawłem II, Rzym 1982, s. 19. 
Może zaskakiwać, że dla człowieka, który był myślicielem, filozofem i teologiem, a także mistykiem, człowiekiem kontemplacji, inspirujące było duszpasterstwo, czyli dziedzina praksis, strefa zewnętrznej aktywności. Tym bardziej, że nawet w pracy naukowej bardziej go interesował element analizy niż strona praktyczna czy techniczna gromadzenia informacji. Sam siebie tak scharakteryzował: „Z usposobienia jestem bardziej myślicielem niż erudytą - i tak też było w ciągu mojej stosunkowo krótkiej pracy w Krakowie i Lublinie"13. Mimo takich predyspozycji to właśnie duszpasterstwo, które jest wyrazem ewangelicznej troski o człowieka, otworzyło go na tajemnicę osoby.

Wszystko jednak zaczęło się na dobre od sfatygowanych butów. Dwie studentki nowo powstałej po II wojnie światowej Politechniki Krakowskiej, która znalazła swoją siedzibę kilkaset metrów od kościoła św. Floriana, gdzie od 1949 roku wikarym był ks. Karol Wojtyła, wpadły na pomysł założenia duszpasterstwa akademickiego i udały się na poszukiwania przyszłego duszpasterza do kościoła. Tam spotkały idącego do konfesjonału ks. Wojtyłę. Tak wspomina jedna z nich o tym, co przesądziło, że wybrały właśnie jego:

Wówczas zafascynowało nas [...] coś prostego, coś, co kontrastowało w wyglądzie zewnętrznym z sylwetką innych „świeżo upieczonych” księży. Ich wypielęgnowany wygląd, nienaganna fryzura, sutanna ,spod igły” i nieskazitelnie wyczyszczone buty (nawet od spodu) budziły wątpliwość, czy w takich butach można dotrzeć przez często brudne lub zabłocone ulice do tych, którzy najbardziej potrzebują pomocy. Tymczasem idący przez kościół ksiądz miał mocno sfatygowaną sutannę (nawet $\mathrm{z}$ dyskretną łatą od dołu) i jeszcze bardziej sfatygowane buty... Te buty powiedziały nam więcej o młodym wikarym, niż jego starannie przygotowane kazanie, którego wysłuchałam z Teresą w najbliższą niedzielę.

[...] Już wiedziałyśmy! Mamy akademickiego duszpasterza! I to według naszych kryteriów... ideał! No bo i niesforny kosmyk na czole... i łata na wysłużonej sutannie... i przede wszystkim te wspaniałe wysłużone buty wzbudziły w nas wręcz zachwyt. One dotrą wszędzie i nie odstraszy ich ani błoto, ani kamienie, ani odległośćc ${ }^{14}$.

${ }^{13}$ A. Frossard, „Nie lękajcie się”..., dz. cyt., s. 19.

${ }^{14}$ Z. Lubertowicz, Buty, w: Zapis drogi. Wspomnienia o nieznanym duszpasterstwie księdza Karola Wojtyły, red. A. Świerczek, Kraków 20052, s. 128. 
Tak rozwinęło się duszpasterstwo, które z czasem przybrało nazwę „,Rodzinki” lub „Środowiska”, a duszpasterza nazywano Wujkiem. Miało ono różne wymiary. Podejmowano konkretne akcje duszpasterskie, np. powstanie chóru wykonującego śpiewy gregoriańskie podczas mszy św., misteria paschalne, studium Sumy teologicznej św. Tomasza (w lacińskim oryginale), ale także prywatne spotkania i rozmowy, szczególnie podczas wycieczek poza miasto, a później większych wypraw w góry i nad jeziora. Cechami charakterystycznymi tego duszpasterstwa, na które zwracają uwagę uczestnicy, była przede wszystkim bliska obecność ks. Wojtyły i towarzyszenie we wszystkich sprawach, małych i dużych, z którymi zwracali się do swojego duszpasterza ${ }^{15}$. Podejście Wojtyły do każdego z uczestników duszpasterstwa było bardzo indywidualne. Jedna z uczestniczek, Danuta Ciesielska, wspomina:

Nie wiem, czy zdawaliśmy sobie sprawę, jak Wujek nad nami pracował. Oczywiście $\mathrm{z}$ każdym (lub prawie $\mathrm{z}$ każdym) indywidualnie, nie tylko w konfesjonale, ale służąc nam właściwie nieograniczenie swoim czasem, by wysłuchać, wyjaśnić, podpowiedzieć, podprowadzić do decyzji. Równocześnie było to działanie niezwykle dyskretne. To były propozycje, nie nakazy. Pamiętam - po latach odważyłam się zapytać, a właściwe zarzucić Wujkowi, że tak mało od nas wymaga. Stwierdził, że jest naprawdę wymagający. Lecz pozostawia nam wolny wybór ${ }^{16}$.

To poszanowanie osobistej wolności w podejmowaniu decyzji podkreśla wielu uczestników tamtego duszpasterstwa ${ }^{17}$. Duszpasterstwo było miejscem odkrywania indywidualności i niepowtarzalności osoby, bo uświadamiało,

15 Por. Jan Paweł II, Dar i tajemnica..., dz. cyt., s. 61. Jedna z pierwszych uczestniczek duszpasterstwa wspomina: „O zawrót głowy przyprawiało Jego uszanowanie, umiłowanie i zatroskanie człowiekiem” (T. Skawińska, On rozda miłość, Paryż 1997, s. 23).

${ }_{16}$ D. Ciesielska, Ze wspomnień najistotniejszych, w: Zapis drogi..., dz. cyt., s. 63. W książce Miłość i odpowiedzialność Wojtyła pisze, że to uszanowanie wolności człowieka w jego wyborach jest także cechą działania Boga. Zob. K. Wojtyła, Miłość i odpowiedzialność, Lublin 19864, s. 30.

${ }_{17}$ Maria Tarnowska: „Nie znałam nigdy innego duszpasterza, który potrafiłby połączyć jasność i pewność oceny i wskazań z tak pełnym pozostawieniem podopiecznemu jego osobistej wolności i godności. Nigdy nie czułam się przez Wujka do niczego zmuszoną, a przecież Go słuchałam” (Wujek i Środowisko, w: Zapis drogi..., dz. cyt., s. 278). Stanisław Rybicki: „podczas gdy ja mówiłem do niego godzinami, nigdy nie usłyszałem, żeby powiedział: «radziłbym ci to a to». Raczej rzucał światło na problem. Ale potem zawsze mówił: "ty musisz zdecydować»" (G. Weigel, Świadek nadziei..., dz. cyt., s. 140). 
że każdy człowiek jest inny i trzeba do niego podejść w sposób indywidualny, a także zdawać się na jego własne decyzje.

Tę osobistą, zaangażowaną bliskość sam Wojtyła określał pojęciem „uczestnictwa”. Nie tylko obserwował i słuchał, ale przeżywał i czynił swoimi doświadczenie młodych ludzi, a zarazem dzielił się z nimi swoim osobistym przeżywaniem wiary i swoją wiedzą teologiczną. Było to prawdziwe communio personarum - wzajemna wymiana darów, o której jako papież wielokrotnie będzie mówił w odniesieniu do osoby i wspólnoty osób: „KKomunia» dotyczy relacji międzyosobowej pomiędzy «ja» $\mathrm{i}$ «ty». «Wspólnota» natomiast zdaje się ten układ przekraczać w kierunku «społeczności», w kierunku jakiegoś «my»"18. To doświadczenie interpersonalnej relacji, która jest fundamentem każdej wspólnoty przywołuje na myśl inną wersję definicji osoby zaproponowaną przez augustiańskiego mnicha Ryszarda od św. Wiktora († 1173): „intellectualis naturae incommunicabilis existentia"19, wskazującą na relacyjny wymiar osoby. Osoba potrzebuje drugiej osoby, nie tylko żeby się móc wyrazić, ale także żeby móc zrozumieć i doświadczyć siebie jako osoby, poniekąd w ten sposób stworzyć swoją osobowość. Zarazem ludzkie communio personarum jest odbiciem Boskiej komunii Osób w Trójcy Świętej ${ }^{20}$, wszak człowiek jest stworzony na obraz i podobieństwo Boga. Dlatego też osobowy kontakt z drugim

18 Jan Paweł II, List do rodzin Gratissimam sane, Kraków 1994, nr 7. Natomiast w Novo millenio ineunte kreśli zasadnicze rysy tego, co definiuje jako „duchowość komunii”: „Duchowość komunii to przede wszystkim spojrzenie utkwione w tajemnicy Trójcy Świętej, która zamieszkuje w nas i której blask należy dostrzegać także w obliczach braci żyjących wokół nas. Duchowość komunii to także zdolność odczuwania więzi z bratem w wierze dzięki głębokiej jedności mistycznego Ciała, a zatem postrzegania go jako «kogoś bliskiego», co pozwala dzielić jego radości i cierpienia, odgadywać jego pragnienia i zaspokajać jego potrzeby, ofiarować mu prawdziwą i głęboką przyjaźń. Duchowość komunii to także zdolność dostrzegania w drugim człowieku przede wszystkim tego, co jest w nim pozytywne, a co należy przyjąć i cenić jako dar Boży: dar nie tylko dla brata, który bezpośrednio go otrzymał, ale także «dar dla mnie». Duchowość komunii to wreszcie umiejętność «czynienia miejsca» bratu, wzajemnego «noszenia brzemion» i odrzucania pokus egoizmu, które nieustannie nam zagrażają, rodząc rywalizację, bezwzględne dążenie do kariery, nieufność, zazdrość. Nie łudźmy się: bez takiej postawy duchowej na niewiele zdałyby się zewnętrzne narzędzia komunii. Stałyby się bezdusznymi mechanizmami, raczej pozorami komunii niż sposobami jej wyrażania i rozwijania" (Jan Paweł II, Novo millenio ineunte, Poznań 2001, nr 43).

19 Richardus a Sancto Victore, De Trinitate, IV, 22, in: Richardi a Sancto Victore opera omnia, tomus unicus, accurante J.-P. Migne, Parisiis 1855 (Patrologiae Cursus Completus. Series Latina, 196), kol. 945.

${ }^{20}$ Por. Jan Paweł II, Mężczyzną i niewiastą stworzył ich. Odkupienie ciała a sakramentalność małżeństwa, Watykan 1986, s. 39-40. 
człowiekiem miał dla Wojtyły zawsze wymiar religijny, był prowadzeniem do Boga - duszpasterstwem właśnie.

W efekcie swoich doświadczeń ze studentami Wojtyła wypracowuje metodologię duszpasterskiego zgłębiania osoby: obserwować i słuchać - zrozumieć w świetle Ewangelii - wyrazić językiem filozofii i teologii. Duszpasterstwo ks. Wojtyły było prowadzeniem młodych, uczenia ich życia ludzkiego i chrześcijańskiego, ale zarazem było dla samego Wojtyły okazją do uczenia się człowieka. Tak to wyraziła Danuta Ciesielska: „Byliśmy poletkiem doświadczalnym dla jego idei. Wzrastaliśmy w naszym życiu rodzinnym i zawodowym, a on uczył się od nas. Ale nie byliśmy zarozumiali z tego powodu, że go czegoś nauczyliśmy; to była wzajemna wymiana"21.

Wszystkie te doświadczenia znalazły później odbicie w twórczości filozoficznej i teologicznej Jana Pawła II:

Tak więc - podsumowuje papież - genealogia moich prac skoncentrowanych na człowieku, na osobie ludzkiej, jest przede wszystkim duszpasterska ${ }^{22}$.

\section{Spotkanie ze św. Janem od Krzyża}

Oprócz sfatygowanych butów, tym, co ujęło i przekonało młodych ludzi do tego, że Wojtyła będzie najlepszym kandydatem na ich duszpasterza, był fakt, że lubi się modlić. Kiedy przyszli na pierwszą rozmowę w sprawie duszpasterstwa kościelny powiedział im, że młody wikary modli się w kościele. Tak ten moment zapamiętała Teresa Skawińska:

Jak się okazało, ksiądz Karol Wojtyła nie miał zwyczaju modlić się zbyt krótko, do istotnych i chyba najważniejszych chwil dnia był zaliczony czas modlitwy [...]. I to była pierwsza lekcja dla nas, jeszcze przed wygłaszaniem konferencji. Przykład. Lekcja przyjęta z prawdziwym zaciekawieniem i interpretacją w pokoju studenckim: modli się przed południem w zamkniętym kościele ${ }^{23}$.

Kształtowanie się osobistej pobożności człowieka jest zawsze owiane tajemnicą, bo ostatecznie przewodnikiem w tym dziele jest Duch Święty, który w różny sposób przemawia do ludzkiego serca i sumienia. Niemniej jednak

\footnotetext{
${ }^{21}$ G. Weigel, Świadek nadziei..., dz. cyt., s. 143.

${ }^{22}$ Jan Paweł II, Przekroczyć próg nadziei, dz. cyt., s. 149.

${ }_{23}$ T. Skawińska, On rozda miłość, dz. cyt., s. 25-26.
} 
można w tym wczesnym okresie życia Wojtyły wskazać na jedną osobę, która odegrała w tym procesie ważną rolę. Był nią Jan Tyranowski (1901-1947), opiekun w czasie wojny męskich grup Żywego Różańca na krakowskich Dębnikach, do których należał Wojtyła. Już jako papież, wspominając swoją drogę do kapłaństwa, przyzna, że od niego nauczył się „między innymi elementarnych metod pracy nad sobą" ${ }^{24}$ oraz to, że wprowadził go w lekturę św. Jana od Krzyża. Tym tekstom poświęcił później swój doktorat na temat wiary ${ }^{25}$, który zasadniczo dotyczył kwestii teologicznych, ale w tle obecna była prawda o człowieku, o czym pisał w swoim artykule na łamach krakowskiego „Znaku” O humanizmie św. Jana od Krzyża $a^{26}$.

Studiując św. Jana od Krzyża, Wojtyła odkrywa, że pełne poznanie prawdy o człowieku wymaga wejścia na drogę doświadczenia wewnętrznego, którego najwyższym przejawem jest doświadczenie mistyczne. Zarazem to doświadczenie wewnętrzne jest tak bogate, że może je wypełnić jedynie Bóg. Prawda człowieka ma zatem swoje korzenie w większej prawdzie, jaką jest Bóg. Jednocząc się z Nim w wierze, człowiek odkrywa swoją osobową wartość, tzn. radykalną inność od rzeczy. Interpretując z pozycji filozofa pracę nad św. Janem od Krzyża, Rocco Buttiglione zwraca uwagę na fakt odkrycia przez Wojtyłę transcendencji osoby, fakt, że człowiek jest nieredukowalny do rzeczy, co szczególnie staje się jasne w przeżyciu nocy ciemnej zmysłów i ducha, kiedy wszystkie „przedmiotowe” obrazy Boga stają się bezwartościowe. W ten sposób

Wiedza o nieprzedmiotowości przedmiotu poznania jest najwyższym rodzajem wiedzy, jaką człowiek może mieć o Bogu. Jest to wiedza o tym, że Bóg nie może być pojęty jako przedmiot, lecz jako osoba, którą poznać można jedynie w relacji wzajemnego daru. Za sprawą daru człowiek przebywa w osobowym wnętrzu Boga, a Bóg we wnętrzu człowieka ${ }^{27}$.

${ }^{24}$ Jan Paweł II, Dar i tajemnica..., dz. cyt., s. 25.

${ }_{25}$ Doctrina de fide apud S. Joannem a Cruce, wyd. pol. Zagadnienie wiary $w$ dziełach św. Jana od Krzyża, tłum. o. Leonard od Męki Pańskiej ocD, Kraków 1990.

${ }^{26} \mathrm{~W}$ doświadczeniu życia łaską, opisanym przez św. Jana od Krzyża ujawnia się podmiotowość człowieka we wszystkich jego najgłębszych dynamizmach życia wewnętrznego. „Można więc mówić o rzeczywistej postaci humanizmu w dziełach św. Jana od Krzyża, bo zjednoczenie z Bogiem i cały zespół sił, które mu bezpośrednio służą, zawiera w sobie prawdziwą humanistyczną treść, jest sprawą człowieka” (K. Wojtyła, O humanizmie św. Jana od Krzyża, „Znak” 6 (1951) nr 1 (27), s. 17).

27 R. Buttiglione, Myśl Karola Wojtyły, Lublin 1996, s. 82. 
Studia nad św. Janem od Krzyża były tym samym inspiracją do wypracowania własnych założeń antropologicznych, w których istotną rolę będzie odgrywać doświadczenie, zwłaszcza doświadczenie wewnętrzne, odsłaniające ludzkiego ducha ${ }^{28}$, oraz zakorzenienie ludzkiego ducha i jego istoty w Bogu, będącym Bytem osobowym ofiarującą się człowiekowi w miłości ${ }^{29}$.

\section{Pierwsze refleksje o człowieku}

Jedną z inicjatyw duszpasterstwa akademickiego były czwartkowe spotkania w kościele św. Floriana, na których ks. Wojtyła wygłaszał konferencje odnoszące się do podstawowych problemów religijnych ${ }^{30}$. Był to okres, kiedy wraz $\mathrm{z}$ ideologią komunistyczną rozpoczęła się w Polsce programowa ateizacja, zmierzająca do przedefiniowania życia społecznego i historii narodu. Dlatego tematem pierwszych konferencji była kwestia istnienia Boga, a właściwe możliwości Jego poznania i mówienia o Bogu: O poznawalności i poznaniu $B o g a^{31}$. Wspominając ten okres już jako papież w rozmowie z Vittorio Messorim, stwierdził, że początkowo wydawało mu się, iż polem intelektualnej konfrontacji z marksizmem będzie filozofia przyrody. Szybko jednak okazało się, że to człowiek będzie centralnym problemem tej dyskusji ${ }^{32}$. Dlatego drugi cykl konferencji poświęcony został temu tematowi: Rozważania o istocie człowieka. Wojtyła stwierdza, że punktem wyjścia jego rozważań o człowieku jest doświadczenie.

Stwierdziliśmy, że w naszych rozważaniach punkt wyjścia jest doświadczalny. Łączymy to ściśle $\mathrm{z}$ realizmem poznawczym, nasze bowiem poznanie dosięga rzeczywistości, dotyka jej niejako w całym bogatym zespole jej przejawów,

${ }^{28}$ Wagę doświadczenia w poznaniu człowieka podkreśli Wojtyła wyraźnie w artykule poświęconym św. Janowi od Krzyża: „Zasada wglądu i doświadczenia obowiązuje u podstaw wszelkiego humanizmu” (K. Wojtyła, O humanizmie św. Jana od Krzyża, dz. cyt. s. 7).

${ }_{29}$ Por. J. Galarowicz, Człowiek jest osoba. Podstawy antropologii filozoficznej Karola Wojtyty, Kraków 1994, s. 13-35.

30 W kronice parafialnej św. Floriana zanotowano ten fakt: „Młodzież akademicka zwróciła się do nas z prośbą o umożliwienie jej udziału w konferencjach religijnych specjalnie dla tej młodzieży głoszonych. Spełniając to życzenie od czwartku i potem co tydzień będą głoszone konferencje dla młodzieży akademickiej o godz. 20. Treścią będzie systematyczny wykład nauki wiary” (2o listopada 1949) (Kalendarium życia Karola Wojtyły, red. A. Boniecki, Kraków 1983, s. 111).

${ }^{31}$ K. Wojtyła, O poznawalności i poznawaniu Boga, Kraków 2000.

${ }^{32}$ Zob. Jan Paweł II, Przekroczyć próg nadziei, dz. cyt., s. 147-150. 
które bezpośrednio się narzucają naszemu poznaniu. Jeśli tedy o człowieka chodzi - to stanowi on najbliższy przedmiot owego poznania doświadczalnego i ponad to - przedmiot stosunkowo najlepiej znany. Tak więc każdy z nas posiada pewną doświadczalną wiedzę o człowieku poprzez własne ja, a prócz tego przez obserwację porównawczą innych ludzi ${ }^{33}$.

Takie podejście odpowiadało zarówno realistycznej filozofii św. Tomasza, jak i bliskiej Wojtyle fenomenologicznej metodzie oglądu przedmiotu, jak też ogólnej wrażliwości człowieka pooświeceniowego na wiedzę doświadczalną, czy wreszcie odpowiadało tej wiedzy, którą Wojtyła nabywał w trakcie kontaktu duszpasterskiego z młodymi.

Wiedza płynąca z doświadczenia człowieka jest jednak wielowymiarowa, dotyczy wielu aspektów, a to sprawia, że grozi jej fragmentaryczność, a przez to jednostronność. Chodzi o to „w jaki sposób różnorodne i różnokierunkowe osiągnięcia tych nauk scalić w prostą i ścisłą wiedzę o człowieku” ${ }^{\prime 34}$. Jest to - jak stwierdza Wojtyła - zadaniem filozofii, która wskazuje na duszę ludzką, jako tę, która „kryje w sobie tajemnice ludzkiej istoty, w niej się ześrodkują te siły życiowe, które o istocie człowieka ostatecznie stanowią. [...] Dusza oznacza w nim zawsze samo źródło i zasadę życia, źródło wszystkich przejawów życiowych"35. Tak więc przestrzeń doświadczenia człowieka ma charakter duchowy, jest doświadczeniem jego życia duchowego, w tym szczególnie jego samoświadomości i wolności.

Dodajmy w tym miejscu, że kilkanaście lat później pisząc rozprawę filozoficzną Osoba i czyn, Wojtyła rozpocznie ją właśnie od zwrócenia uwagi na doświadczenie człowieka. Pierwsze zdanie książki brzmi: „Studium niniejsze powstaje $\mathrm{z}$ potrzeby obiektywizacji w dziedzinie tego wielkiego procesu poznawczego, który można określić u podstaw jako doświadczenie człowieka"36. U podstaw tego doświadczenia osoby czyn ogrywa szczególną rolę, dlatego że ujawnia on osobę. To jest punkt wyjścia całej refleksji Wojtyły: „czyn stanowi szczególny moment ujawnienia osoby" ${ }^{37}$, która jest jego podmiotem sprawczym w sposób świadomy i wolny.

\footnotetext{
${ }^{33}$ K. Wojtyła, Rozważania o istocie człowieka, Kraków 1999, s. 18-19.

${ }^{34} \mathrm{~K}$. Wojtyła, Rozważania o istocie człowieka, dz. cyt., s. 19.

${ }_{35}$ K. Wojtyła, Rozważania o istocie człowieka, dz. cyt., s. 23.

${ }^{36}$ K. Wojtyła, Osoba i czyn, Kraków 19852, s. 5. Pierwsze wydanie ukazało się w 1969 roku.

${ }^{37}$ K. Wojtyła, Osoba i czyn, dz. cyt., s. 15.
} 
W kontekście ateizmu materialistycznego, z którym musiała się zmagać ówczesna młodzież, Wojtyła zamierzał bronić prawdy o człowieku, wskazując na jego wymiar duchowy. Ów wymiar decyduje zarazem o tym, że człowiek nie jest tylko jednostką, jedną z wielu, przynależną do określonego gatunku, lecz jest jednostką wyjątkową samą w sobie i niepowtarzalną, co stanowi o jego godności - jest osobą.

Człowiek - to nie tylko indywiduum ludzkiego gatunku, ale to przede wszystkim pewna wewnętrzna duchowa treść ściśle niepowtarzalna, właściwa tylko tej jednostce, treść, której nie da się przypisać innemu ,ja”, do niego odnieść, w nim jako własną uświadomić, za nią wreszcie jako za własną ponieść odpowiedzialnośćc ${ }^{38}$.

\section{Przygotowanie do małżeństwa a doświadczenie osoby}

Naturalnym tematem podejmowanym przez młodych w rozmowach ze swoim duszpasterzem był temat miłości, sprawa wyboru przyszłego małżonka, podejmowanie decyzji o ślubie czy wreszcie problemy, jakie wiązały się z samym życiem małżeńskim. Jako papież wspomina, że młodzi przychodzili do niego „nie tyle z pytaniami o istnienie Boga, ale z pytaniami o to, jak żyć. Jak żyć, to znaczy jak znaleźć rozwiązanie dla problemów miłości i małżeństwa, a także dla problemów pracy zawodowej. [...] Z obcowania z nimi, z uczestniczenia w ich życiowych problemach, zrodziło się naprzód studium, którego treść zawarłem w tytule Miłość i odpowiedzialnośc" 39 .

W ten sposób w doświadczenie osoby weszło zagadnienie kluczowe dla osoby, jakim jest miłość, będące zarazem centralnym tematem książki, która ukazała się w 1960 roku. Kluczem hermeneutycznym całej rozprawy jest prawda o człowieku, który jako jedyny jest podmiotem, w przeciwieństwie do wszystkiego innego, co należy do świata przedmiotów. O podmiotowości osoby decyduje jego życie wewnętrzne i życie duchowe, które koncentruje się wokół prawdy i dobra, czyli zdolności do poznania i docierania do prawdy oraz zdolności wyboru poznanego dobra. Z tego względu osoba „nie może być ani wyłącznie, ani przede wszystkim przedmiotem używania z tej racji, że rola ślepego narzędzia czy też środka do celu zamierzonego przez inny

${ }^{38}$ K. Wojtyła, Rozważania o istocie człowieka, dz. cyt., s. 96.

39 Jan Paweł II, Przekroczyć próg nadziei, dz. cyt., s. 149. 
podmiot sprzeciwia się jej naturze"40, ale jako podmiot domaga się wyjątkowego traktowania, odpowiadającego temu, kim jest ${ }^{41}$. Także w relacji między mężczyzną i kobietą, która z psychologicznego punktu widzenia przeżywana jest jako uczucie miłości. Na czym polega istotna treść tej relacji, decydująca o etycznym wymiarze miłości?

Wojtyła stawia zasadnicze pytanie, które jest od zawsze obecne w sercu młodego człowieka: czy istnieje prawdziwa miłość i na czym ona polega? Odpowiedź jest prosta, choć mało romantyczna, ze względu na to, że nie odwołuje się do emocjonalnych przeżyć i całej strefy reakcji z tym związanych.

Co to znaczy miłość prawdziwa? To znaczy taka, w której realizuje się prawdziwa istota miłości, która zwraca się do prawdziwego (nie tylko pozornego) dobra, i to w sposób prawdziwy, czyli taki, jaki odpowiada jego naturze ${ }^{42}$.

Chodzi zatem o prawdę samego przedmiotu miłości, a także o prawdę relacji, jaka nas wiąże z owym przedmiotem. Odpowiedź Wojtyły jest taka, po pierwsze, że prawdziwym dobrem dla drugiego człowieka, który jest osobą, może być tylko osoba. Po wtóre, odniesienie do osoby w miłości musi być adekwatne do jej osobowej godności, to znaczy musi być aktem afirmacji osoby: „I w tym właśnie wyraża się podstawowy rys etyczny miłości: jest ona afirmacją osoby, bez tego zaś nie jest miłością"43. Ten akt afirmacji integruje, absorbuje w sobie wszystkie inne wartości, które tkwią w człowieku, w tym także jego seksualność. Tę normę, która wymaga akceptacji drugiego ze względu na to, że jest osobą Wojtyła, nazywa „normą personalistyczną”.

Norma ta jako zasada o treści negatywnej stwierdza, że osoba jest takim dobrem, z którym nie godzi się używanie, które nie może być traktowane jako przedmiot użycia i w tej formie jako środek do celu. W parze $\mathrm{z}$ tym idzie treść

$4^{40}$ K. Wojtyła, Miłość i odpowiedzialność, dz. cyt., s. 30-31.

${ }^{41}$ Wojtyła pisze, że w ten sposób traktuje człowieka także Bóg: „Skoro Bóg zamierza człowieka do jakichś celów skierować, to przede wszystkim daje mu te cele poznać, tak aby człowiek mógł je uczynić swoimi i samodzielnie do nich dążyć. W tym leży m.in. najgłębsza logika objawienia: Bóg daje człowiekowi poznać cel nadprzyrodzony, ale decyzja dążenia do tego celu, jego wybór, jest pozostawiony wolności człowieka. Dlatego też Bóg nie zbawia człowieka wbrew jego woli”

(K. Wojtyła, Miłość i odpowiedzialność, dz. cyt., s. 30).

${ }^{42}$ K. Wojtyła, Miłość i odpowiedzialność, dz. cyt., s. 77.

${ }^{43}$ K. Wojtyła, Miłość i odpowiedzialność, dz. cyt., s. 110. 
pozytywna normy personalistycznej: osoba jest takim dobrem, że właściwe i pełnowartościowe odniesienie do niej stanowi tylko miłość ${ }^{44}$.

Już jako papież wspomina, że norma ta była próbą przełożenia na język filozoficznej etyki przykazania miłości. Wskazuje zarazem, że pełną interpretację tej normy odnajdujemy w stwierdzeniu Soboru Watykańskiego II z konstytucji Gaudium et spes: „Człowiek będąc jedynym na ziemi stworzeniem, którego Bóg chciał dla niego samego, nie może odnaleźć się w pełni inaczej, jak tylko poprzez bezinteresowny dar z siebie samego" ( $\mathrm{nr} 24)^{45}$. To zdanie jest jednym z najczęściej przywoływanych tekstów soborowych w magisterium papieża. Jest bowiem podsumowaniem personalistycznego myślenia Karola Wojtyły, a zarazem znajdzie szerokie rozwinięcie i pogłębienie w teologii ciała Jana Pawła II, przede wszystkim w drugiej części, mówiącej o bezinteresownym darze $\mathrm{z}$ siebie samego.

Tak więc - komentuje papież - te dwa aspekty: afirmacja osoby dla niej samej oraz bezinteresowny dar z siebie samego, nie tylko wzajemnie się nie wykluczają, ale się potwierdzają wzajemnie i w sobie zawierają. Człowiek najpełniej afirmuje siebie, dając siebie. To jest pełna realizacja przykazania miłości. To jest równocześnie pełna prawda o człowieku, której Chrystus nauczył nas swoim życiem; prawda, którą potwierdza szeroko tradycja moralności chrześcijańskiej, jak również tradycja świętych i tylu bohaterów miłości bliźniego w ciągu dziejów ${ }^{46}$.

\section{Filozoficzne studium na temat osoby}

Rozprawa Osoba i czyn, która ukazała się w 1969 roku, zrodziła się z tego samego źródła, co duszpasterstwo młodzieży i spotkanie ze św. Janem od Krzyża, a mianowicie $z$ doświadczenia człowieka ${ }^{47}$. Przesłaniem dzieła Wojtyły była prawda o ontycznej spójności osoby, jedności egzystencjalnej, której świa-

${ }^{44}$ K. Wojtyła, Miłość i odpowiedzialność, dz. cyt., s. 42. „Osoba jest takim bytem, że właściwym do niej odniesieniem jest miłość. Jesteśmy sprawiedliwi wobec osoby, jeżeli ją miłujemy - tak Boga, jak i ludzi. Miłość osoby wyklucza traktowanie jej jako przedmiotu użycia" (Jan Paweł II, Przekroczyć próg nadziei, dz. cyt., s. 150).

45 Por. Jan Paweł II, Przekroczyć próg nadziei, dz. cyt., s. 150.

${ }^{46}$ Jan Paweł II, Przekroczyć próg nadziei, dz. cyt., s. 150-151.

47 „Praca na temat osoby i czynu powstała później, ale zrodziła się z tego samego źródła. Poniekąd nie można było do tego tematu nie dojść, skoro już się raz wkroczyło na obszar tych 
domość siebie i samostanowienie łączą się w jedno w jej działaniu, poprzez które osoba się wyraża i spełnia zarazem ${ }^{48}$. Dzięki temu człowiek jest zawsze podmiotem, a nie tylko przedmiotem działania; jest zawsze „kimś”, a nie tylko „Czyms'”49. Człowiek, właśnie jako osoba, posiada swoją własną, wewnętrzną wartość, a ponieważ jest ona jedyna w sobie i nieporównywalna z żadną inną wartością, mówimy w tym wypadku o godności. Prawda o tym, kim człowiek jest jako osoba, nie wyczerpuje się tylko w odniesieniu do indywidualnego wymiaru jego życia, osoba $z$ natury swojej jest otwarta na inne osoby i jest wezwana do współpracy z drugimi, właśnie jako osobami, a nie przedmiotami mojego działania.

Książka Osoba i czyn kończy się analizą takich pojęć i odpowiadających im rzeczywistości, jak: „uczestnictwo” we wspólnocie i „solidarność, dzięki której „człowiek znajduje spełnienie siebie w dopełnianiu innych” ${ }^{50}$. Pojęcia te wchodzą do refleksji filozoficznej i społecznej, na długo przed tym, jak staną się ideą przewodnią odzyskania w Polsce wolności. „Pisząc o tym w Osobie i czynie - komentuje Weigel - nie mógł wiedzieć, że solidarność stanie się sztandarem, pod którym historia dwudziestego wieku ulegnie dramatycznej przemianie" ${ }^{51}$.

\section{Teologia ciała}

Dopełnieniem duszpasterskiego podejścia do człowieka, ubogaconego już o filozoficzne studium na temat miłości i samej osoby, są katechezy o małżeństwie, wygłaszane podczas audiencji środowych od 1979 do 1984 roku. Rozpoczynając je, Jan Paweł II, kierując się wskazaniem Chrystusa zawartym w rozmowie z faryzeuszami (por. Mt 19, 3-8), odwołuje się w poszukiwaniu prawdy o małżeństwie, a zarazem prawdy o samym człowieku, która stoi u podstaw natury małżeństwa, do „początku”, rozumianego jako moment ukonstytuowania człowieka w akcie stworzenia, a więc do biblijnego opisu stworzenia człowieka.

egzystencjalnych pytań o człowieka, a myślę, że chodzi tu nie tylko o człowieka naszych czasów, ale poniekąd o człowieka wszystkich czasów” (K. Wojtyła, Przekroczyć próg nadziei, dz. cyt., s. 149).

${ }^{48}$ Por. R. Buttiglione, Myśl Karola Wojtyły, dz. cyt., s. 175-253.

${ }^{49}$ Por. K. Wojtyła, Osoba i czyn, dz. cyt., s. 95.

${ }^{50}$ K. Wojtyła, Osoba i czyn, dz. cyt., s. 352.

${ }^{51}$ G. Weigel, Świadek nadziei..., dz. cyt., s. 227. 
Pierwszy opis ma charakter bardziej teologiczny, gdyż określenie istoty człowieka czerpie on z jego odniesienia do Boga: jest Jego obrazem i podobieństwem; drugi opis ujmuje człowieka w aspekcie jego podmiotowości, odsłania subiektywną stronę jego życia wewnętrznego i zawiera w sobie „in nucleo wszystkie te elementy analizy człowieka, na które stała się wrażliwa nowożytna, a zwłaszcza współczesna antropologia filozoficzna. Można powiedzieć, że Rdz 2 ukazuje stworzenie człowieka nade wszystko w aspekcie jego podmiotowości"s2.

Kluczowym momentem drugiego opisu jest stworzenie kobiety, a raczej mężczyzny i kobiety jako jedności dwojga. Rozpoczyna się ono od doświadczenia pierwotnej samotności Adama, która jest rezultatem braku utożsamienia się $\mathrm{z}$ widzialnym światem (mimo iż łączy go $\mathrm{z}$ nim podobieństwo ciała), a zarazem brakiem świadomości tego, kim jest on sam.

Oto stworzony człowiek znajduje się od pierwszej chwili swego istnienia wobec Boga niejako w poszukiwaniu swojej istoty, rzec można w poszukiwaniu swej definicji. Myśliciel współczesny powiedziałby może: w poszukiwaniu swej tożsamości. Stwierdzenie, że jest sam wśród widzialnego świata, a w szczególności wśród istot żyjących ma dla tych poszukiwań znaczenie o tyle negatywne, że wyraża się w stwierdzeniu kim nie jestem. [...] Człowiek jest sam, jest bowiem inny $\mathrm{w}$ stosunku do widzialnego świata, do świata istot żyjących ${ }^{53}$.

Owej samotności nie znosi spotkanie $\mathrm{z}$ widzialnym światem, przede wszystkim światem istot żyjących (animalia), którym Adam nadaje nazwy. Jest to pierwszy krok do uczynienia dla człowieka stosownej „pomocy”. Jednak $\mathrm{z}$ żadnym z tych zwierząt człowiek się nie zidentyfikował, nie odkrył że jest pomocą „dla” niego. Jan Paweł II pisze, że był to swoisty test, czy też egzamin przed Bogiem, poprzez który człowiek uświadamia sobie „swoją nadrzędność - czyli «niesprowadzalność» do żadnego rzędu (gatunku) istot żyjących na ziemi”"54.

Po tym doświadczeniu Adam zapada w głęboki sen, w czasie którego Bóg wyjmuje jego żebro i stwarza kobietę. Jan Paweł II komentuje ten sen jako inny wyraz aktu stwórczego Boga: powołanie z niebytu do istnienia, bowiem w kulturze starożytnej sen traktowano jako analogię śmierci (sen ma w sobie

${ }^{52}$ Jan Paweł II, Mężczyzna i niewiastą stworzyt ich..., dz. cyt., s. 14-15.

53 Jan Paweł II, Mężczyzna i niewiasta stworzył ich..., dz. cyt., s. 25-27.

${ }^{54}$ Jan Paweł II, Mężczyzną i niewiastą stworzył ich..., dz. cyt., s. 25. 
coś z unicestwienia świadomego bytowania człowieka) ${ }^{55}$. Przy czym ten akt stwórczy odnosi się tym razem do świadomości człowieka, do jego ducha: człowiek rodzi się duchowo, to znaczy zdobywa świadomość tego, kim jest jako człowiek.

Pojawienie się kobiety, w której mężczyzna odczytuje tożsamość swojej własnej osoby („kość z kości”), ale zarazem odrębność, stanowiącą dopełnienie dla jego męskości, pozwala mu uwolnić się od przeżywanej samotności. Człowiek odkrywa, kim jest nie tylko jako mężczyzna, ale jako człowiek właśnie. To jest rzeczywista „pomoc” dla Adama. Nie tylko jako wypełnienie samotności poprzez obecność kogoś innego, która przynosi wielorakie skutki i owoce (np. rozmowa, praca, budowanie relacji itp.), ale zasadniczo jako pomoc do tego, by człowiek odkrył swoją tożsamość, by odkrył, że jest osobą, co wiąże się jednocześnie $\mathrm{z}$ odkryciem sensu bycia osobą, to znaczy bycia ukierunkowanym na drugiego, a nawet jeszcze bardziej radykalnie: bycia dla drugiego. To właśnie ujawnia się w doświadczeniu pomocy, czyli wzajemnego obdarowania. Papież pisze:

Tak więc owe dwa wyrażenia: z jednej strony „sam”, a z drugiej „pomoc”, wydają się po prostu kluczowe dla zrozumienia samej istoty daru na poziomie człowieka, jako treści egzystencjalnej wpisanej w całą prawdę „obrazu Bożego”. Dar bowiem ujawnia jakby szczególną prawidłowość bytowania osobowego - owszem, samego osobowego istnienia. Kiedy Jahwe Bóg stwierdza: „nie jest dobrze, ażeby człowiek był sam” (Rdz 2, 18), wskazuje, iż „sam” nie spełnia tej prawidłowości. Spełnia ją, bytując „Z kims” - i jeszcze głębiej, jeszcze gruntowniej: bytując „dla kogos”” ${ }^{\prime}$.

W ten sposób mężczyzna w kobiecie (ale zarazem i odwrotnie kobieta w mężczyźnie) odnajduje zasadniczą pomoc-dar dla siebie, a jednocześnie odkrycie to stanowi podstawę tworzenia wspólnoty (communio personarum), w której poprzez wzajemne dopełnienie pokonuje się pierwotną samotność i odkrywa się istotę człowieczeństwa, bycia osobą. Podstawowym wymiarem ludzkiego

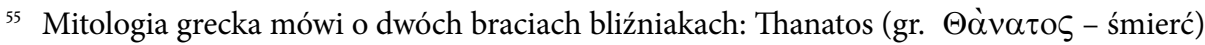

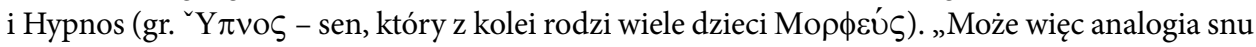
wskazuje tutaj nie tyle na zstępowanie ze świadomości w podświadomość, ile raczej na swoisty powrót do niebytu (sen ma w sobie coś z unicestwienia świadomego bytowania człowieka) do momentu przed stworzeniem, aby z niego mocą stwórczej inicjatywy Boga «człowiek» samotny mógł się wyłonić «człowiekiem» w jedności dwojga: mężczyzną i niewiastą" (Jan Paweł II, Mężczyznq i niewiasta stworzył ich..., dz. cyt., s. 35).

${ }^{56}$ Jan Paweł II, Mężczyzną i niewiastą stworzył ich..., dz. cyt., s. 57-58. 
bytowania jest zdolność, a zarazem powinność bycia darem dla drugiego, to znaczy życia w miłości. Człowiek nie może się inaczej odnaleźć - wydobyć z metafizycznej samotności - jak tylko poprzez miłość, czyli bezinteresowny dar dla drugiej osoby. Owo krótkie wyrażenie „dla” zdaniem papieża „opisuje podstawową prawidłowość osobowego bytowania”57 człowieka. Stając się darem dla drugiego, człowiek spełnia sens swojego osobowego istnienia i bytowania. Zarazem taki sposób osobowego bytowania człowieka jest podstawą tworzenia komunii osób (communio personarum), co jednocześnie potwierdza i urzeczywistnia prawdę o stworzeniu człowieka na obraz i podobieństwo Boga.

Taką prawdą o człowieku św. Jan Paweł II starał się kierować w całym swoim życiu i kapłańskim powołaniu, jakie otrzymał. Ta prawda kazała mu wyruszać na poszukiwanie każdego człowieka i docierać do najodleglejszych miejsc i do różnorodnych środowisk, w których żyje człowiek. „Być dla drugiego”, najpierw jako człowiek, później jako kapłan i jako papież - oznaczało dla Jana Pawła II być dla drugiego świadkiem Chrystusa. Sfatygowane buty krakowskiego duszpasterza młodzieży zaprowadziły go w 104. pielgrzymkach do niemal każdego zakątka świata.

\section{ABSTRAKT}

Jednym z głównych wątków bogatego magisterium św. Jana Pawła II jest tematyka antropologiczna. Pytanie o człowieka, o jego naturę, jego egzystencjalny etos i ostateczne powołanie, które odnajduje w Bogu, było tematem pierwszej, programowej encykliki Redemptor hominis. Jednak geneza zainteresowania tematem człowieka była wcześniejsza i sięga początków formacji intelektualnej i duchowej Karola Wojtyły, a także jego pracy kapłańskiej. Znaczącym elementem tej historii jest duszpasterstwo młodzieży akademickiej w Krakowie. Stało się ono nie tylko praktycznym polem doświadczenia człowieka, ale i inspiracją do naukowej refleksji filozoficzno-teologicznej. Jej owocem były dwa dzieła, w których Wojtyła formułuje zarys swojego personalizmu integralnego: Miłość i odpowiedzialność oraz Osoba i czyn. Zawarta w nich analiza podmiotowości człowieka będzie później fundamentem jego nauczania o godności osoby ludzkiej, której najgłębszy fundament znajduje się w stworzeniu

\footnotetext{
57 Jan Paweł II, Mężczyzną i niewiastą stworzył ich..., dz. cyt., s. 59.
} 
człowieka na obraz i podobieństwo Boga, w odkupieniu dokonanemu przez Chrystusa i powołaniu człowieka do wspólnoty miłości z Bogiem w wieczności.

Artykuł przedstawia zasadnicze linie tego rozwoju, począwszy od pierwszych konferencji na temat człowieka skierowanych do krakowskich studentów, aż po teologię ciała, rozwijaną w trakcie środowych audiencji w Watykanie.

\section{SŁOWA KLUCZOWE}

Karol Wojtyła, Jan Paweł II, antropologia, duszpasterstwo, godność osoby, miłość, teologia ciała

\section{ABstract}

From the destroyed shoes to the anthropology of the gift. The pastoral genesis of the personalism of Saint John Paul II

One of the main themes of the rich magisterium of St. John Paul II is an anthropological theme. The question about man, his nature, his existential ethos and the ultimate vocation he finds in God was the subject of the first, program encyclical Redemptor hominis. However, the genesis of his interest in the topic of man was much earlier and dates back to the beginnings of the intellectual and spiritual formation of Karol Wojtyła, as well as his priestly work. A significant element of this story is the pastoral care of the university students in Krakow. It has become not only a practical field of the experience of every human being, but also an inspiration for the scientific philosophical and theological reflection. Its fruit were two works in which Wojtyła formulates an outline of his integral personalism: Love and responsibility, and Person and act. The analysis of the human subjectivity contained in them will later become the foundation of his teaching on the dignity of the human person, whose deepest foundation is being created in the image and likeness of God, redemption by Christ and man's vocation to communion with God in eternity.

The article presents the main lines of this development starting from the first conferences on the topic of man addressed to students in Krakow to the theology of the body, developed during the Wednesday audiences in the Vatican.

\section{KeYWORDS}

Karol Wojtyła, John Paul II, anthropology, dignity of the person, love, theology of the body 


\section{BIBLIOGRAFIA}

Buttiglione R., Myśl Karola Wojtyły, Lublin 1996.

Frossard A., „Nie lękajcie się”. Rozmowy z Janem Pawłem II, Rzym 1982.

Galarowicz J., Człowiek jest osobą. Podstawy antropologii filozoficznej Karola Wojtyły, Kraków 1994.

Jan Paweł II, Dar i tajemnica. W pięćdziesiąta rocznicę moich święceń kapłańskich, Kraków 1996.

Jan Paweł II, List do rodzin Gratissimam sane (2 lutego 1994), Kraków 1994.

Jan Paweł II, Mężczyzna i niewiastą stworzył ich. Odkupienie ciała a sakramentalność małżenstwa, Watykan 1986.

Jan Paweł II, List apostolski Novo millenio ineunte (6 stycznia 2001), Poznań 2001. Jan Paweł II, Przekroczyć próg nadziei, Lublin 1994.

Jan Paweł II, Encyklika Redemptor hominis (4 marca 1979), Lublin 1982.

Jan Paweł II, „Szkoła dla człowieka” sprzyja spotkaniu z Chrystusem. Audiencja dla nauczycieli szkół średnich, członków Włoskiego Katolickiego Związku Nauczycieli Szkół Średnich (3 listopada 1979), w: Nauczanie papieskie, t. 2, cz. 2, s. 493-495.

Jan Paweł II, Tu mas mis au tréfonds. List apostolski z okazji pięćdziesiątej rocznicy wybuchu II wojny światowej (27 sierpnia 1989), https://ekai.pl/papiez-na-lecie-wybuchu-wojny/.

Skawińska T., On rozda miłość, Paryż 1997.

Sobór Watykański II, Konstytucja duszpasterska o Kościele w świecie współczesnym Gaudium et spes, w: Sobór Watykański II, Konstytucje, dekrety, deklaracje, Poznań 2002, s. 526-606.

Weigel G., Świadek nadziei. Biografia Papieża Jana Pawła II, Kraków 2000.

Wojtyła K., Doctrina de fide apud S. Joannem a Cruce, wyd. pol. Zagadnienie wiary w dziełach św. Jana od Krzyża, tłum. o. Leonard od Męki Pańskiej ocD, Kraków 1990.

Wojtyła K., Miłość i odpowiedzialność, Lublin $1986^{4}$.

Wojtyła K., O humanizmie św. Jana od Krzyża, „Znak” 6 (1951) nr 1 (27), s. 6-20.

Wojtyła K., O poznawalności i poznawaniu Boga, Kraków 2000.

Wojtyła K., Osoba i czyn, Kraków $1985^{2}$.

Wojtyła K., Rozważania o istocie człowieka, Kraków 1999.

Zapis drogi. Wspomnienia o nieznanym duszpasterstwie księdza Karola Wojtyly, red. A. Świerczek, Kraków $2005^{2}$. 